\title{
Effect of Camel Milk on the Physicochemical, Rheological, and Sensory Qualities of Bread
}

\author{
Noha M. Almoraie $\mathbb{i}$ and Israa M. Shatwan $(\mathbb{D}$ \\ Food and Nutrition Department, Faculty of Human Sciences and Design, King Abdulaziz University, Jeddah, Saudi Arabia \\ Correspondence should be addressed to Noha M. Almoraie; nalmorie@kau.edu.sa
}

Received 22 September 2020; Revised 19 January 2021; Accepted 25 May 2021; Published 1 June 2021

Academic Editor: Francesco Genovese

Copyright (C) 2021 Noha M. Almoraie and Israa M. Shatwan. This is an open access article distributed under the Creative Commons Attribution License, which permits unrestricted use, distribution, and reproduction in any medium, provided the original work is properly cited.

\begin{abstract}
An increase in bread production has been achieved to meet the increasing demand of the growing population. During the manufacturing process, refined wheat flour, the main ingredient for bread making, loses its nutritional qualities. Hence, it is necessary to use additional nutritional sources to maintain nutritional value. In this study, the rheological, physicochemical, and sensory qualities of bread, prepared using camel milk and water, were evaluated. The increase in the camel milk content resulted in the significant increase in the protein, oil, and ash contents of bread and a decrease in the carbohydrate content. The protein content was increased from $11.95 \%$ (100\% water) to $14.01 \%$ (100\% camel milk). The use of camel milk resulted in the progressive increase in the content of two essential fatty acids, $\alpha$-linolenic acid and linoleic acid $(P<0.05$; maximum increase: $1.65 \%$ and $20.9 \%$, resp.). The rheological properties of bread (peak viscosity, gelatinisation temperature, and water absorption capacity) could be improved using camel milk. However, reduced dough stability and peak viscosity-temperature were also observed. The increase in the water absorption capacity from $61 \%$ to $67 \%$ indicated that the supplemented dough was more suitable than the original dough for preparing bread. The physical properties of bread prepared using camel milk (30\%) and water (70\%) were better than the properties of the control bread sample. Improved sensory attributes were observed under these formulation conditions. Bread containing $\geq 70 \%$ camel milk received lower sensory scores. The results indicated that the use of the formulation consisting of camel milk (30\%) and water (70\%) could enhance the nutritional value of bread without significantly affecting the acceptability. The results can provide a platform for extending the application of camel milk, primarily used to produce fermented milk, in the food industry. It could be potentially used to address the global problem of acute malnutrition.
\end{abstract}

\section{Introduction}

Bread, a basic foodstuff consumed daily worldwide, is usually made using wheat flour [1]. The production and consumption of foods such as bread have increased considerably owing to the rapid population growth [2]. There is a demand for the incorporation of functional ingredients to improve the quality of wheat-based bread products [3] and to compensate for the loss of important nutrients, such as dietary fibre, antioxidant compounds, and various vitamins and minerals, during wheat milling processes [4]. Additionally, wheat flour is considered low in protein content because of its lack of essential amino acids, such as lysine and threonine [5]. Hence, the enrichment of bread with bioactive components is an important goal for improving the health of consumers [6] (particularly the health of consumers residing in Saudi Arabia who regularly consume bread).

As one of the most important animals for Bedouins in the Arabian Peninsula, camels are a main source of livelihood (primarily camel milk). Approximately 30 million tons of camel milk are produced each year, mostly in the Middle East, according to the FAO [7]. Furthermore, fresh milk and dairy products made from camel milk are becoming increasingly available in European markets [8]. Camel milk is considered a good source of protein, with a protein content of $3.00-3.90 \%$. Caseins, including $\beta$-casein (65\%) and whey proteins (20-25\%), are the major proteins in camel milk [9]. Additionally, camel milk is characterised by high levels of vitamins $(0.50-2.50 \%)$ and minerals (0.60-0.90\%). Iron (0.21-0.29 mg/100 g), sodium (58-59 mg/100 g), zinc 
TABle 1: Bread making method.

\begin{tabular}{|c|c|c|c|c|c|}
\hline Ingredient & $\mathrm{C} 0: \mathrm{W} 100$ & $\begin{array}{l}\mathrm{C} 30: \mathrm{W} 70 \\
(\%)\end{array}$ & $\begin{array}{l}\text { C50 : W50 } \\
(\%)\end{array}$ & $\begin{array}{l}\text { C70 : W30 } \\
(\%)\end{array}$ & $\begin{array}{l}\text { C100: W0 } \\
(\%)\end{array}$ \\
\hline Wheat flour & $100 \%$ & & & & \\
\hline Water & $100 \%$ & 70 & 50 & 30 & 0 \\
\hline Camel milk & 0 & 30 & 50 & 70 & 100 \\
\hline Salt & $2 \%$ & & & & \\
\hline Sugar & $5 \%$ & & & & \\
\hline Instant yeast & $3 \%$ & & & & \\
\hline Margarine & $3 \%$ & & & & \\
\hline $\begin{array}{l}\text { Dough mixing time/mixing } \\
\text { speed }\end{array}$ & $5 \mathrm{~min} / 235 \mathrm{rpm}$ & & & & \\
\hline $\begin{array}{l}\text { Dough fermentation } \\
\text { conditions }\end{array}$ & $\begin{array}{c}30^{\circ} \mathrm{C}, \mathrm{RH} 75 \%, 90 \mathrm{~min} \text { (transfixion after } \\
60 \mathrm{~min} \text { ) }\end{array}$ & & & & \\
\hline Dough proofing conditions & $30^{\circ} \mathrm{C}, \mathrm{RH} 75 \%, 60 \mathrm{~min}$ & & & & \\
\hline Baking conditions & $230^{\circ} \mathrm{C}, 30 \mathrm{~min}$ & & & & \\
\hline
\end{tabular}

RH: relative humidity.

(0.19-0.53 mg/100 g), potassium (156-179 mg/100 g), magnesium (10.40-14.00 mg/100 g), and cholesterol (3.00-5.00 g/kg of milk fat; low content) are also found in camel milk [10-12]. Several studies on camel milk have identified various health benefits, such as anticarcinogenic, antidiabetic, and antiviral effects [9, 13]. Camel milk is a good choice for children allergic to bovine milk [8]. It reduces cholesterol and blood pressure [9]. Therefore, camel milk is considered a good source of nutrition [14]. Accordingly, the enrichment of food products with camel milk has the potential to enhance the rheological, nutritional, and organoleptic properties [15]. Although camel milk has recently been used to prepare various food items, such as cheese, beverages, ice cream, and yogurt, its use to prepare baked goods is not common [16-20]. Thus, the main aim of this study was to evaluate the effects of camel milk present in bread formulations on the physicochemical and sensory attributes of bread.

\section{Materials and Methods}

2.1. Materials. Wheat flour (75\% extraction) was purchased from the Grain Silos and Flour Mills Organization (Jeddah, Saudi Arabia). Camel milk was obtained from the Emirates Industry for Camel Milk and Products (EICMP, Dubai, United Arab Emirates). Margarine, salt, and sugar were obtained from local markets in Jeddah, Saudi Arabia. All chemicals used in the study were of analytical grade.

2.2. Bread Preparation. Bread samples were prepared based on the official standard method [21]. To obtain different composite dough formulations, the water was replaced with $0 \%, 30 \%, 50 \%, 70 \%$, or $100 \%$ camel milk (Table 1). The baking conditions are outlined in Table 1. The formulation containing $100 \%$ water was used as the control for the characterisation of different properties.

2.3. Sample Characterisation. To determine the moisture content, the samples were weighed before and after drying in an oven (AOAC 935.29). The Kjeldahl method was used to determine the protein content (AOAC 988.05). The oil and ash contents were determined using the Soxhlet method (AOAC 963.15) and the drying method (AOAC 942.05), respectively. The fibre content was also determined using an enzymatic-gravimetric method (AOAC 985.29). The carbohydrate content was calculated by the difference method by subtracting the sum of other components from 100. Gas chromatography (AOC-20i; Shimadzu, Tokyo, Japan) was used to determine the fatty acid compositions of the dough and bread samples. For these measurements, fatty acid methyl esters were prepared according to the European standard [22]. Lipid standards (Sigma Aldrich, St. Louis, MO, USA) were used to identify the fatty acids.

The rheological properties of the wheat dough samples containing various concentrations of camel milk were investigated following the standard methods of the American Association of Cereal Chemists [23]. Farinograph and amylograph measurements were based on AACC54-21 and 54-10, respectively, and were conducted using instruments obtained from C.W. Brabender Instruments, Inc. (South Hackensack, NJ, USA).

Loaf weight, loaf volume, and specific loaf volume were evaluated to determine the physical characteristics of the bread samples. A laboratory scale (CE- 410I; Camry Emperors, China) was used to measure the loaf weight $0.5 \mathrm{~h}$ after removal from the oven. The loaf volume was measured using the modified rapeseed displacement method, as reported by Giami et al. [24]. As described by Araki et al. [25], the specific loaf volume was determined as follows: specific loaf volume $=$ loaf volume/loaf weight.

To the best of our knowledge, a limited number of studies have been conducted in the presence of liquid dairy using a farinograph. We followed the procedure outlined in the previously reported studies [26, 27]. The standard methods reported by the American Association of Cereal Chemists were modified to prepare the dough. Breads were manufactured in $1000 \mathrm{~g}$ flour batches, using the modified straight dough method. The dry ingredients (flour, sugar, yeast, salt, and margarine) were homogenized at slow speed for $1 \mathrm{~min}$. Following this, varying amounts of water and camel milk $(30,50$, and $100 \%$ of the added water) were added 
TABle 2: Proximate compositions of wheat bread samples with different concentrations of camel milk.

\begin{tabular}{lccccc}
\hline Parameter & C0:W100 & C30:W70 & C50:W50 & C70:W30 & C100:W0 \\
\hline Moisture (\%) & $8.45^{\mathrm{e}} \pm 0.12$ & $7.17^{\mathrm{b}} \pm 0.09$ & $6.14^{\mathrm{a}} \pm 0.27$ & $7.25^{\mathrm{c}} \pm 0.10$ & $8.13^{\mathrm{d}} \pm 0.01$ \\
Protein (\%) & $11.95^{\mathrm{a}} \pm 0.21$ & $12.21^{\mathrm{b}} \pm 0.45$ & $12.75^{\mathrm{c}} \pm 0.43$ & $13.47^{\mathrm{d}} \pm 0.31$ & $14.01^{\mathrm{e}} \pm 0.21$ \\
Ash (\%) & $2.45^{\mathrm{a}} \pm 0.55$ & $2.57^{\mathrm{b}} \pm 0.41$ & $2.66^{\mathrm{c}} \pm 0.19$ & $2.71^{\mathrm{d}} \pm 0.93$ & $2.91^{\mathrm{e}} \pm 0.01$ \\
Fat (\%) & $2.19^{\mathrm{a}} \pm 0.23$ & $2.33^{\mathrm{b}} \pm 0.10$ & $3.11^{\mathrm{c}} \pm 0.11$ & $3.27^{\mathrm{d}} \pm 0.21$ & $3.34^{\mathrm{e}} \pm 0.01$ \\
Linoleic acid (\%) & $19.1^{\mathrm{a}} \pm 0.22$ & $19.2^{\mathrm{b}} \pm 0.65$ & $20.1^{\mathrm{c}} \pm 0.34$ & $20.4^{\mathrm{d}} \pm 0.15$ & $20.9^{\mathrm{e}} \pm 0.23$ \\
$\alpha$-Linolenic acid (\%) & $1.17^{\mathrm{a}} \pm 0.12$ & $1.21^{\mathrm{b}} \pm 0.28$ & $1.57^{\mathrm{c}} \pm 0.21$ & $1.62^{\mathrm{d}} \pm 0.33$ & $1.65^{\mathrm{e}} \pm 0.61$ \\
Carbohydrate (\%) & $79.21^{\mathrm{e}} \pm 0.29$ & $75.10^{\mathrm{d}} \pm 0.32$ & $75.04^{\mathrm{c}} \pm 0.92$ & $73.21^{\mathrm{b}} \pm 0.24$ & $70.15^{\mathrm{a}} \pm 0.34$ \\
Fibre (\%) & $2.12^{\mathrm{c}} \pm 0.16$ & $1.91^{\mathrm{a}} \pm 0.10$ & $2.21^{\mathrm{d}} \pm 0.11$ & $2.27^{\mathrm{e}} \pm 0.19$ & $2.11^{\mathrm{b}} \pm 0.45$ \\
Energy (kcal/100g) & $320.1^{\mathrm{a}} \pm 0.01$ & $371.1^{\mathrm{b}} \pm 0.48$ & $376.4^{\mathrm{c}} \pm 0.57$ & $383.4^{\mathrm{d}} \pm 0.55$ & $291.2^{\mathrm{e}} \pm 0.20$ \\
\hline
\end{tabular}

Mean \pm standard deviation $(n=3)$. Different letters in the same row represent significant differences between samples $(P \leq 0.05)$. C0:W100: 100\% water (control), C30 : W70: 70\% water and 30\% camel milk, C50:W50: 50\% water and 50\% camel milk, C70: W30: 30\% water and 70\% camel milk, and C100: W0: $100 \%$ camel milk.

based on the optimum absorption capacity of the flour sample (55-100g-1 f.b.), as determined by farinograph, considering the water present in camel milk, discounting its soluble solids content. Further mixing was carried out during $5 \mathrm{~min}$ (235 rpm). A ball-shaped dough was formed, which was fermented at $30^{\circ} \mathrm{C}$ (RH: $75 \%$; time: $90 \mathrm{~min}$; transfixed after $60 \mathrm{~min}$ ). Following this, the fermented dough was passed through a bread-forming machine and placed on baking pans. After fermentation, the dough was baked for $30 \mathrm{~min}$ at $230^{\circ} \mathrm{C}$ using an electric rotary oven. Loaves were removed from the moulds and cooled for $0.5 \mathrm{~h}$ at room temperature $23^{\circ} \mathrm{C}$ before analysis.

Sensory assessments of the bread samples were performed $2 \mathrm{~h}$ after baking by 50 females selected from the students, staff, and faculty members of King Abdulaziz University, Jeddah, Saudi Arabia. The sensory qualities of the external and internal properties of the bread were evaluated using a five-point hedonic scale ( $5=$ like, $1=$ dislike). The colour, texture, taste, flavour, and overall acceptability of the bread were evaluated. The bread samples were coded with a three-digit random number and served to the panelists in random order. The sensory analysis was performed in three sessions, and the mean values of 50 evaluations were calculated and used for each sample and session during the data analysis.

2.4. Statistical Analysis. The means and standard deviations of the obtained data were analysed using SPSS version 26 (SPSS Inc., Chicago, IL, USA). Three measurements were obtained for each sample. The differences between the treatment means were analysed by conducting the one-way analysis of variance (ANOVA) and Tukey's tests. Differences were considered statistically significant at $P \leq 0.05$.

\section{Results and Discussion}

3.1. Proximate Composition of Bread. The proximate compositions of the bread samples made from wheat flour supplemented with different concentrations of camel milk $(0 \%, 30 \%, 50 \%, 70 \%$, or $100 \%$ of added water) are displayed in Table 2. Overall, the incorporation of camel milk in bread formulations significantly increased the protein, fat, $\alpha$-linolenic acid (omega-3 fatty acid), linoleic acid (omega- 6 fatty acid), and ash contents of the bread samples and decreased the carbohydrate content. The increases in protein, fat, and ash can be directly attributed to the added camel milk, which contains appreciable amounts of these constituents. The bread supplemented with $100 \%$ camel milk (C100: W0) in Table 2 had the highest protein, fat, and ash contents, whereas the control sample (C0:W100) had the lowest values, suggesting that these constituents depend on the concentration of camel milk.

In agreement with our findings, several studies have reported that the supplementation of wheat flour with various legume flours, whey protein concentrate, or milk powder increases the protein, oil, and ash contents but reduces the carbohydrate content of fortified bread $[6,28,29]$. Therefore, it could be inferred that an increase in the protein content could improve the nutritional quality of bread. Animal proteins are considered more nourishing and have higher amino acid contents when compared to the cereal proteins. Accordingly, breads supplemented with camel milk could have beneficial effects on the nutritional and health status of the consumers.

3.2. Rheological Properties of Dough. Farinograph and amylograph analyses were used to determine the rheological properties of the dough samples consisting of wheat flour supplemented with different concentrations of camel milk. The farinograph results indicated that supplementation with camel milk considerably affected the water absorption capacity, degree of softening, and dough stability (Table 3 ). As the concentration of camel milk in the dough gradually increased, the absorption of water increased $(P \leq 0.05)$ from $61 \%$ for the control $(\mathrm{C} 0: \mathrm{W} 100)$ to $67 \%$ for the sample supplemented with $100 \%$ camel milk (C100:W0). This increase may result from the increase in the protein solubility and protein content following the addition of camel milk, as the proteins are characterised by high absorption capacity, hydrophobicity, and solubility [26]. Moreover, the addition of camel milk could lead to structural changes in the dough, allowing greater water absorption via increased hydrogen bonding [26]. The water absorption capacity is an indicator of the dough consistency. A high-water absorption capacity is attractive for bread making. Additionally, the quantity of water is important for the distribution and 
TABLE 3: Rheological properties of wheat dough samples with different concentrations of camel milk.

\begin{tabular}{|c|c|c|c|c|c|}
\hline Characteristic & $\mathrm{C} 0: \mathrm{W} 100$ & C30:W70 & C50:W50 & $\mathrm{C} 70: \mathrm{W} 30$ & C100:W0 \\
\hline Water absorption (\%) & $61.0^{\mathrm{a}} \pm 0.34$ & $62.5^{\mathrm{b}} \pm 0.21$ & $64.0^{c} \pm 0.12$ & $65.0^{\mathrm{d}} \pm 0.01$ & $67.0^{\mathrm{e}} \pm 0.45$ \\
\hline Dough stability (min) & $9.4^{\mathrm{e}} \pm 0.45$ & $8.6^{\mathrm{d}} \pm 0.45$ & $8.4^{\mathrm{c}} \pm 0.15$ & $8.2^{\mathrm{b}} \pm 0.12$ & $8.1^{\mathrm{a}} \pm 0.30$ \\
\hline Degree of softening (BU) & $23.0^{\mathrm{c}} \pm 0.20$ & $23.0^{c} \pm 0.23$ & $22.0^{\mathrm{b}} \pm 0.40$ & $21.0^{\mathrm{a}} \pm 0.01$ & $21.0^{\mathrm{a}} \pm 0.20$ \\
\hline Gelatinisation temperature $\left({ }^{\circ} \mathrm{C}\right)$ & $61.1^{\mathrm{a}} \pm 0.12$ & $61.9^{\mathrm{b}} \pm 0.12$ & $63.2^{\mathrm{C}} \pm 0.13$ & $63.9^{\mathrm{d}} \pm 0.12$ & $64.2^{\mathrm{e}} \pm 0.45$ \\
\hline Peak viscosity (BU) & $671^{\mathrm{a}} \pm 0.11$ & $783^{\mathrm{b}} \pm 0.65$ & $832^{\mathrm{c}} \pm 0.21$ & $896^{\mathrm{d}} \pm 0.34$ & $956^{\mathrm{e}} \pm 0.05$ \\
\hline Temperature at peak viscosity $\left({ }^{\circ} \mathrm{C}\right)$ & $88.1^{\mathrm{e}} \pm 0.12$ & $86.2^{\mathrm{d}} \pm 0.09$ & $83.9^{\mathrm{C}} \pm 0.16$ & $82.5^{\mathrm{b}} \pm 0.10$ & $80.9^{\mathrm{a}} \pm 0.21$ \\
\hline
\end{tabular}

Mean \pm standard deviation $(n=3)$. Different letters in the same row represent significant differences between samples $(P \leq 0.05)$. C0:W100: 100\% water (control), C30:W70: 70\% water and 30\% camel milk, C50: W50: 50\% water and 50\% camel milk, C70: W30: 30\% water and 70\% camel milk, and C100: W0: $100 \%$ camel milk.

hydration of dough materials as well as the development of a gluten protein network.

Hassan et al. [29] claimed that the replacement of water with various concentrations of buttermilk in bread formulations significantly raises the water absorption capacity of the dough in a concentration-dependent manner. Furthermore, various studies have shown that the addition of dairy products, nut or legume flours, and vegetable or protein isolates to wheat flour significantly increases the capacity for water absorption [30, 31]. In contrast, Madenci and Bilgiçli [32] asserted that the addition of dairy by products (whey protein concentrates and buttermilk powder) to wheat flour decreases the water absorption capacity of dough.

The stability of the dough decreased as the concentration of camel milk in the dough increased. This reduction in stability could be explained by camel milk components able to disrupt the wheat gluten-starch network by competing with the proteins from wheat flour for water. The proteolytic activity exhibited by the camel milk hydrolysate likely reduced the stability of wheat gluten. In line with our findings, Hassan et al. [29] reported a decline in dough stability for bread formulations with high contents of acidic whey, buttermilk, and skim milk powder. Gadallah et al. [33] noted a similar reduction in dough stability with the addition of increasing amounts of legume flour.

Although camel milk fortification had a generally positive impact on the water absorption capacity and an adverse effect on dough stability, its effects on the degree of softening were minor. However, as shown in Table 3, compared to $100 \%$ water, the fortification of wheat flour with camel milk significantly increased the gelatinisation temperature and peak viscosity. A reduction in the temperature at peak viscosity $(P \leq 0.05)$ was also observed. The increase in the peak viscosity and gelatinisation temperature could be attributed to the properties of lactose (which promotes starch gelatinisation) present in camel milk. The substitution of water by lactose sugar results in a decrease in the moisture content inside the starch granule, resulting in an increase in gelatinisation temperature [34]. The pasting properties were affected by the carbohydrate and protein contents of flour. The improvement in the pasting properties could be attributed to the decrease in the carbohydrate and increase in the protein contents [35]. In our study, we substituted water with milk. The starch (carbohydrate) content of bread did not decrease. An increase in the starch content could be attributed to the lactose content of milk. The pasting properties improved as the temperature decreased. The results are consistent with the previously reported result obtained by studying wheat flour supplemented with cereal, legume, vegetable, or sago flour $[28,30,31,36]$. However, the addition of protein isolates from legumes reduced the maximum viscosity of the dough [37]. This inconsistency could be due to the difference in materials, as protein isolates are free of sugars or starches, whereas all other materials contain sugars and starches that can increase the viscosity and gelatinisation temperature.

3.3. Physical Characteristics of Bread. Table 4 shows the physical characteristics of the composite bread samples with different percentages of camel milk. Compared with the control (C0:W100), wheat flour supplemented with camel milk resulted in a significantly higher $(P \leq 0.05)$ bread weight and volume. Bread loaves with higher weights and volumes are typically preferred by consumers. The heaviest loaf was obtained at $100 \%$ camel milk supplementation $(\mathrm{C} 100: \mathrm{W} 0)(P \leq 0.05)$. The observed increase in bread weight at higher concentrations of camel milk may be due to the increased ability of the supplemented dough to absorb water (Table 3). Furthermore, the increase in the value weight for camel milk bread could be attributed to the large size and distribution of casein micelles in camel milk. The size distribution of casein micelles in camel milk was approximately $468 \pm 1.00 \mathrm{~nm}$. It was $137 \pm 1.50 \mathrm{~nm}$ for cow milk $[8,38,39]$. The loaf volume $\left(1019.3 \pm 0.21 \mathrm{~cm}^{3}\right)$ and specific volume $\left(4.15 \pm 0.34 \mathrm{~cm}^{3} / \mathrm{g}\right)$ were highest for $30 \%$ camel milk supplementation $(P \leq 0.05)$, followed by $50 \%$, $70 \%$, and $100 \%$ camel milk supplementation. Although the loaf specific volume was reduced by supplementation with high amounts of camel milk ( $70 \%$ and $100 \%)$, the values were still within $3.0-6.0 \mathrm{~cm}^{3} / \mathrm{g}$, which is characteristic of regular bread, as identified by the China Grain Products Research and Development Institute [40]. The reductions in loaf volume and specific volume observed for $70 \%$ and $100 \%$ camel milk $(P \leq 0.05)$ may be associated with a decrease in the structure formed by wheat proteins and a low ability of the dough to trap air.

A high dough resistance during handling and preparation may affect the retention of gas in the dough and bread during baking. This can potentially result in a decrease in the loaf volume. In this regard, Moktan and Ojha [6] found that increasing the percentage of germinated horse gram flour 
TABle 4: Physical characteristics of wheat bread samples with different concentrations of camel milk.

\begin{tabular}{|c|c|c|c|c|c|}
\hline Characteristic & $\mathrm{C} 0: \mathrm{W} 100$ & C30 : W70 & C50 : W50 & $\mathrm{C} 70: \mathrm{W} 30$ & C100:W0 \\
\hline Weight (g) & $222.5^{\mathrm{a}} \pm 0.1$ & $245.1^{\mathrm{b}} \pm 0.4$ & $269.6^{c} \pm 0.1$ & $287.1^{\mathrm{d}} \pm 0.1$ & $290.9^{\mathrm{e}} \pm 0.1$ \\
\hline Volume $\left(\mathrm{cm}^{3}\right)$ & $898.1^{\mathrm{b}} \pm 0.1$ & $1019.3^{\mathrm{e}} \pm 0.2$ & $999.5^{\mathrm{d}} \pm 0.4$ & $914.1^{c} \pm 0.2$ & $887.7^{\mathrm{a}} \pm 0.2$ \\
\hline Specific volume $\left(\mathrm{cm}^{3} / \mathrm{g}\right)$ & $4.03^{\mathrm{e}} \pm 0.1$ & $4.15^{\mathrm{d}} \pm 0.3$ & $3.70^{c} \pm 0.3$ & $3.18^{\mathrm{b}} \pm 0.1$ & $3.05^{\mathrm{a}} \pm 0.1$ \\
\hline
\end{tabular}

Mean \pm standard deviation $(n=3)$. Different letters in the same row represent significant differences between samples $(P \leq 0.05)$. C0: W100: 100\% water (control), C30:W70: 70\% water and 30\% camel milk, C50: W50: 50\% water and 50\% camel milk, C70: W30: 30\% water and 70\% camel milk, and C100: W0: $100 \%$ camel milk.

TABLE 5: Sensory evaluation of wheat bread samples with different concentrations of camel milk.

\begin{tabular}{lcccrr}
\hline Parameter & C0:W100 & C30:W70 & C50:W50 & C70:W30 & C100:W0 \\
\hline Crumb colour & $4.50^{\mathrm{b}} \pm 0.11$ & $4.55^{\mathrm{d}} \pm 0.23$ & $4.56^{\mathrm{e}} \pm 0.15$ & $4.48^{\mathrm{a}} \pm 0.14$ & $4.53^{\mathrm{c}} \pm 0.12$ \\
Crumb texture & $4.53^{\mathrm{e}} \pm 0.23$ & $4.51^{\mathrm{d}} \pm 0.10$ & $3.69^{\mathrm{c}} \pm 0.30$ & $2.82^{\mathrm{b}} \pm 0.21$ & $2.77^{\mathrm{a}} \pm 0.11$ \\
Taste and flavour & $4.70^{\mathrm{d}} \pm 0.53$ & $4.82^{\mathrm{e}} \pm 0.12$ & $4.72^{\mathrm{c}} \pm 0.10$ & $4.15^{\mathrm{b}} \pm 0.55$ & $3.95^{\mathrm{a}} \pm 0.73$ \\
Overall acceptability & $4.62^{\mathrm{c}} \pm 0.10$ & $4.66^{\mathrm{e}} \pm 0.45$ & $4.64^{\mathrm{d}} \pm 0.12$ & $3.32^{\mathrm{b}} \pm 0.22$ & $3.13^{\mathrm{a}} \pm 0.77$ \\
\hline
\end{tabular}

Mean \pm standard deviation $(n=3)$. Different letters in the same row represent significant differences between samples $(P \leq 0.05)$. C0:W100: 100\% water (control), C30:W70: 70\% water and 30\% camel milk, C50:W50: 50\% water and 50\% camel milk, C70: W30: 30\% water and 70\% camel milk, and C100: W0: $100 \%$ camel milk.

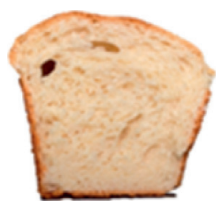

$\mathrm{C} 0: \mathrm{W} 100$

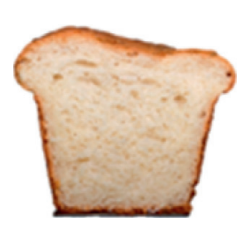

C30:W70

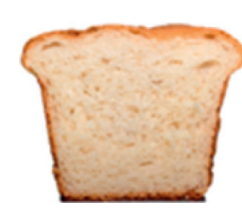

C50:W50

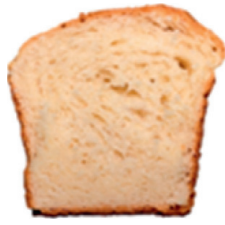

$\mathrm{C} 70: \mathrm{W} 30$

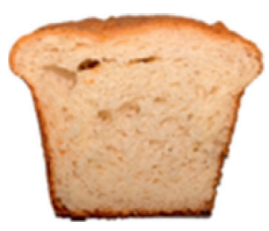

C100:W0

FIGURE 1: Samples used for the sensory evaluation of bread. C0 : W100: 100\% water (control), C30:W70: 70\% water and 30\% camel milk, C50:W50: 50\% water and 50\% camel milk, C70:W30: 30\% water and 70\% camel milk, and C100: W0: 100\% camel milk.

reduces the loaf volume and specific volume but increases the loaf weight. In addition, Gani et al. [37] revealed that casein, casein hydrolysates, whey proteins, and whey protein hydrolysates significantly decrease the specific volume of the loaf.

3.4. Sensory Evaluation of Bread. Sensory evaluations are fundamental for assessing the quality of newly developed food products from the perspective of consumer preferences and needs [41]. The selection of a food product relies on many factors, including health and nutrition, sensory properties, price, value, mood, and experience [42]. Sensory evaluation results for bread made from wheat flour supplemented with different concentrations of camel milk are presented in Table 5. The incorporation of camel milk in the bread formulations did not affect the surface and crumb colour. In contrast, Gani et al. [37] found that increasing the amount of milk protein concentrates and hydrolysates causes a significant change in colour. This colour change can be attributed to a higher degree of browning via the Maillard reaction, which is influenced by the water distribution and the reduction of amino acids and sugars. The results did not agree with the results reported by Gani et al. [37]. They used a different type of milk. The lack of colour change in the current study could be attributed to the lower protein concentration in loaves of bread supplemented with camel milk.

However, supplementation with camel milk did affect other sensory attributes. As compared to the control and the bread supplemented with $30 \%$ camel milk, the inclusion of $70 \%$ and $100 \%$ camel milk significantly reduced the texture of the crumb. The quality scores for taste and flavour ranged from 3.95 to 4.82 (on a 5-point scale), with the highest score observed for the bread prepared with $30 \%$ camel milk, followed by the bread prepared using $50 \%$ camel milk. This trend may reflect the bitter taste of some camel milk components. The overall assessment also indicated that the pieces of bread containing 30\% and 50\% camel milk were preferable to those containing $70 \%$ and $100 \%$ camel milk. Although not significant, the scores of bread containing $30 \%$ camel milk were higher than the scores of the control sample and the bread sample formulated using $70 \%$ and $100 \%$ camel milk in all sensory attributes. These findings indicate that replacing $30 \%$ of the water in bread formulations with camel milk can improve the sensory characteristics of bread (Figure 1).

Similarly, it has been reported that the inclusion of various nut, legume, mushroom flour, and protein isolates in bread affects the sensory qualities of products in a concentration-dependent manner $[6,28,30,36,42]$. Supplementing wheat flour with various concentrations of whey 
protein isolate and buttermilk powder affects the sensory characteristics of bread $[29,32]$. Generally, the results of this study indicated that the nutritional and sensorial attributes of bread could be improved by supplementing bread formulations with $30 \%$ camel milk.

\section{Conclusions}

The present study focused on the use of camel milk to improve the rheological and nutritional qualities of bread without significantly affecting consumer acceptability. The use of camel milk (30\%) and water (70\%) during the preparation of bread significantly improved the rheological properties (water absorption, gelatinisation temperature, and peak viscosity), physical properties (bread weight, volume, and specific volume), and sensory quality of bread. Therefore, supplementation with $30 \%$ camel milk has the potential to improve the nutritional and sensory quality of the bread samples. As people in Saudi Arabia regularly consume bread, this approach could have positive effects on the nutritional and health status of these communities. The use of camel milk for the production of fermented milk is limited (compared to cow milk or milk obtained from other sources). The limited use can be potentially attributed to the chemical structure of camel milk proteins. Therefore, its utilization in the production of bread products may extend the applications of camel milk. The results of this work can also provide a basis for the development of high-energy nutritious mixes. The results of this study can help address the problem of acute malnutrition, which is recognized by the World Health Organization as a major global issue.

\section{Data Availability}

The data used to support the study are included within the article.

\section{Disclosure}

This research was self-funded by the authors.

\section{Conflicts of Interest}

The authors declare that there are no conflicts of interest regarding the publication of this paper.

\section{References}

[1] M. A. Saccotelli, A. Conte, K. R. Burrafato, S. Calligaris, L. Manzocco, and M. A. Del Nobile, "Optimization of durum wheat bread enriched with bran," Food Science \& Nutrition, vol. 5, no. 3, pp. 689-695, 2017.

[2] L. Popper, W. Schäfer, and W. Freund, Future of Flour: A Compendium of Flour Improvement, Agrimedia $\mathrm{GmbH}$, Hamburg, Germany, 2006.

[3] C. Fitzgerald, E. Gallagher, L. Doran, M. Auty, J. Prieto, and M. Hayes, "Increasing the health benefits of bread: assessment of the physical and sensory qualities of bread formulated using a renin inhibitory Palmaria palmata protein hydrolysate," LWT_Food Science and Technology, vol. 56, no. 2, pp. 398405, 2014.
[4] I. Banu, G. Stoenescu, V. S. Ionescu, and I. Aprodu, "Effect of the addition of wheat bran stream on dough rheology and bread quality," Annals of the University of Dunarea de Jos of Galati, vol. 36, no. 1, pp. 39-52, 2012.

[5] V. A. Jideani and F. C. Onwubali, "Optimisation of wheatsprouted soybean flour bread using response surface methodology," African Journal of Biotechnology, vol. 8, no. 22, pp. 6364-6373, 2009.

[6] K. Moktan and P. Ojha, "Quality evaluation of physical properties, antinutritional factors, and antioxidant activity of bread fortified with germinated horse gram (Dolichus uniflorus) flour," Food Science \& Nutrition, vol. 4, no. 5, pp. 766-771, 2016.

[7] FAO, Food and Agriculture Organisation of the United Nations, Food and Agriculture Organisation, Rome, Italy, 2017, http://www.fao.org/faostat/en/\#data/QA/visualize.

[8] E. I. El-Agamy, M. Nawar, S. M. Shamsia, S. Awad, and G. F. W. Haenlein, "Are camel milk proteins convenient to the nutrition of cow milk allergic children?," Small Ruminant Research, vol. 82, no. 1, pp. 1-6, 2009.

[9] D. Kumar, A. K. Verma, M. K. Chatli et al., "Camel milk: alternative milk for human consumption and its health benefits," Nutrition \& Food Science, vol. 46, no. 2, pp. 217-227, 2016.

[10] S. Abbas, H. Ashraf, A. Nazir et al., "Physico-chemical analysis and composition of camel milk," International Research, vol. 2, no. 2, pp. 85-98, 2013.

[11] S. Zibaee, S. M. A.-R. Hosseini, M. Yousefi, A. Taghipour, M. A. Kiani, and M. R. Noras, "Nutritional and therapeutic characteristics of camel milk in children: a systematic review," Electronic Physician, vol. 7, no. 7, pp. 1523-1528, 2015.

[12] G. Konuspayeva, B. Faye, and G. Loiseau, "The composition of camel milk: a meta-analysis of the literature data," Journal of Food Composition and Analysis, vol. 22, no. 2, pp. 95-101, 2009.

[13] R. P. Agrawal, S. Budania, P. Sharma et al., "Zero prevalence of diabetes in camel milk consuming Raica community of northwest Rajasthan, India," Diabetes Research and Clinical Practice, vol. 76, no. 2, pp. 290-296, 2007.

[14] S. Kaskous, "Importance of camel milk for human health," Emirates Journal of Food and Agriculture, vol. 28, no. 3, pp. 158-163, 2016.

[15] U. S. Dubey, M. Lal, and A. Mittal, "Therapeutic potential of camel milk," Emirates Journal of Food and Agriculture, vol. 28, no. 3, pp. 164-176, 2016.

[16] R. Singh, G. Mal, D. Kumar, and N. V. Patil, "Camel milk: an important natural adjuvant," Agricultural Research, vol. 6, no. 4, pp. 327-340, 2017.

[17] I. B. Hashim, A. H. Khalil, and H. Habib, "Quality and acceptability of a set-type yogurt made from camel milk," Journal of Dairy Science, vol. 92, no. 3, pp. 857-862, 2009.

[18] N. Hajian, M. Salami, M. Mohammadian, M. Moghadam, and Z. Emam-Djomeh, "Production of low-fat camel milk functional ice creams fortified with camel milk casein and its antioxidant hydrolysates," Applied Food Biotechnology, vol. 7, no. 2, pp. 95-102, 2020.

[19] T. Walle, M. Yusuf, R. Ipsen et al., "Coagulation and preparation of soft unripened cheese from camel milk using camel chymosin," East African Journal of Sciences, vol. 11, no. 2, pp. 99-106, 2017.

[20] C. S. Ranadheera, N. Naumovski, and S. Ajlouni, "Non-bovine milk products as emerging probiotic carriers: recent developments and innovations," Current Opinion in Food Science, vol. 22, no. 5, pp. 109-114, 2018. 
[21] AOAC, Official Methods of Analysis of AOAC International, Association of Official Analytical Chemists International, Gaithersburg, MD, USA, 18th edition, 2005.

[22] ISO 12966-2:2017, Animal and Vegetable Fats and Oils-Gas Chromatography of Fatty Acid Methyl Esters-Part 2: Preparation of Methyl Esters of Fatty Acids, International Organization for Standardization, Geneva, Switzerland, 2017.

[23] AACC, Approved Methods of the American Association of Cereal Chemists, American Association of Cereal Chemists, Saint Paul, MN, USA, 10th edition, 2000.

[24] S. Y. Giami, T. Amasisi, and G. Ekiyor, "Comparison of bread making properties of composite flour from kernels of roasted and boiled African breadfruit (Treculia africana Decne) seeds," Journal of Raw Material Research, vol. 1, pp. 16-25, 2004.

[25] E. Araki, T. M. Ikeda, K. Ashida, K. Takata, M. Yanaka, and S. Iida, "Effects of rice flour properties on specific loaf volume of one-loaf bread made from rice flour with wheat vital gluten," Food Science and Technology Research, vol. 15, no. 4, pp. 439-448, 2009.

[26] A. H. Al-Jahani, "Effect of buttermilk on the physicochemical, rheological, and sensory qualities of pan and pita bread," International Journal of Food Science, vol. 2017, Article ID 2054252, 8 pages, 2017.

[27] S. M. Al-Eid, A. A. Al-Neshawy, and S. A. Ahmad, "Influence of substituting water with ultrafiltered milk permeate on dough properties and baking quality of white pan bread," Journal of Cereal Science, vol. 30, no. 1, pp. 79-82, 1999.

[28] J. Ndife, L. O. Abdulraheem, and U. M. Zakari, "Evaluation of the nutritional and sensory quality of functional breads produced from whole wheat and soya bean flour blends," African Journal of Food Science, vol. 5, no. 8, pp. 466-472, 2011.

[29] A. A. Hassan, H. A. M. El-Shazly, A. M. Sakr et al., "Influence of substituting water with fermented skim milk, acid cheese whey or buttermilk on dough properties and baking quality of pan bread," World Journal of Dairy \& Food Sciences, vol. 8, no. 1, pp. 100-117, 2013.

[30] I. Mohammed, A. R. Ahmed, and B. Senge, "Dough rheology and bread quality of wheat-chickpea flour blends," Industrial Crops and Products, vol. 36, no. 1, pp. 196-202, 2012.

[31] N. M. Almoraie, "The effect of walnut flour on the physical and sensory characteristics of wheat bread," International Journal of Food Science, vol. 2019, Article ID 5676205, 7 pages, 2019.

[32] A. B. Madenci and N. Bilgiçli, "Effect of whey protein concentrate and buttermilk powders on rheological properties of dough and bread quality," Journal of Food Quality, vol. 37, no. 2, pp. 117-124, 2014.

[33] M. G. E. Gadallah, I. R. S. Rizk, H. E. Elsheshetawy, S. H. Badeir, and A. M. Abouelazm, "Impact of partial replacement of wheat flour with sorghum or chickpea flours on rheological properties of composite blends," Journal of Agricultural and Veterinary Science, vol. 10, no. 1, pp. 83-98, 2017.

[34] M. Iuga, O. Boestean, A. Ghendov-Mosanu, and S. Mironeasa, "Impact of dairy ingredients on wheat flour dough rheology and bread properties," Foods, vol. 9, no. 6, p. 828, 2020.

[35] O. B. Ocheme, O. E. Adedeji, C. E. Chinma et al., "Proximate composition, functional, and pasting properties of wheat and groundnut protein concentrate flour blends," Food Science \& Nutrition, vol. 6, no. 5, pp. 1173-1178, 2018.

[36] E. Pejcz, A. Mularczyk, and Z. Gil, "Technological characteristics of wheat and non-cereal flour blends and their applicability in bread making," Journal of Food and Nutrition Research, vol. 54, no. 1, pp. 69-78, 2015.

[37] A. Gani, A. A. Broadway, F. A. Masoodi et al., "Enzymatic hydrolysis of whey and casein protein- effect on functional, rheological, textural and sensory properties of breads," Journal of Food Science and Technology, vol. 52, no. 12, pp. 7697-7709, 2015.

[38] M. Kamal, M. Foukani, and R. Karoui, "Rheological and physical properties of camel and cow milk gels enriched with phosphate and calcium during acid-induced gelation," Journal of Food Science and Technology, vol. 54, no. 2, pp. 439-446, 2017.

[39] S. Bornaz, A. Sahli, A. Attalah, and H. Attia, "Physicochemical characteristics and renneting properties of camels' milk: a comparison with goats', ewes' and cows' milks," International Journal of Dairy Technology, vol. 62, no. 4, pp. 505-513, 2009.

[40] L. Y. Lin, H. M. Liu, Y. W. Yu, S.-D. Lin, and J.-L. Mau, "Quality and antioxidant property of buckwheat enhanced wheat bread," Food Chemistry, vol. 112, no. 4, pp. 987-991, 2009.

[41] M. Majeed, M. U. Khan, M. N. Owaid et al., "Development of oyster mushroom powder and its effects on physicochemical and rheological properties of bakery products," Journal of Microbiology, Biotechnology and Food Sciences, vol. 6, no. 5, pp. 1221-1227, 2017.

[42] O. L. Erukainure, J. N. C. Okafor, A. Ogunji, H. Ukazu, E. N. Okafor, and I. J. Eboagwu, "Bambara-wheat composite flour: rheological behaviour of dough and functionality in bread," Food Science \& Nutrition, vol. 4, no. 6, pp. 852-857, 2016. 